\title{
Social Ties, Literacy, Location and the Perception of Economic Opportunity: Factors Influencing Telecentre Success in a Development Context
}

\author{
Arlene Bailey \\ The University of the West Indies, Mona, Jamaica \\ arlene.bailey@uwimona.edu.jm
}

\author{
Ojelanki Ngwenyama \\ Ryerson University, Toronto, Canada \\ Ojelanki@ryerson.ca
}

\begin{abstract}
Telecentres have been established in many countries as a means of providing access to information and communication technologies (ICTs) in order to enhance community development. This paper examines the characteristics of telecentre initiatives in Jamaica and proposes a conceptual framework for the assessment of the role of social ties in telecentre success. Social capital and social network theories provide the underpinnings of the theoretical framework for this research, and the empirical analysis draws on interviews with telecentre managers. This paper contributes to the development of theory and guidelines for successful telecentres thereby advancing research and practice in the field of community informatics.
\end{abstract}

\section{Introduction}

A key objective of telecentres in developing countries is the provision of access to ICTs to enable community processes and social development objectives [21]. In this context telecentres are intended to provide citizens with access to the Internet and electronic communication support for community networks, e-governance, and cultural and economic activities $[27,37,57,66]$. While many telecentres have been established and new projects are expanding in developing countries, research is lagging and there is still no clear understanding of the factors that lead to successful and sustainable telecentres [4, 47, 58]. Systematic research on issues pertaining to telecentres in developing countries is growing but still limited [63]. And the challenges of implementing and sustaining telecentres in the face of differing stakeholder interests and resource constraints are formidable for development managers.

In this paper, we report findings from a field study of four telecentres in a specific development context, Jamaica. We use the commonly accepted definition of a telecentre as 'a physical space that provides public access to ICTs for educational, personal, social and economic development' $[24$, p. $73 ; 54$, p.1]. We believe that this definition captures the phenomena we are investigating and reflects the common characteristics of telecentres in other developing country settings. Our research uses qualitative methods including direct observation and in-depth semistructured interviews. The focus of our study is on developing an understanding of factors that influence telecentre usage and success in developing countries.

\section{Research on Telecentre Success}

During the last two decades there has been a growing body of literature on telecentres but there is no consensus on theories for investigating these phenomena $[11,41]$. A variety of studies have focused on different perspectives of ICT media support for communities, telecentres, community access points, community technology centres, cybercentres and community multimedia centres [21]. While these denote differences among the technologies, there are many similarities in services offered and social development purposes. Recent research on telecentres has focused on advancing knowledge on some key questions: (1) What factors affect telecentre success? (2) How to implement / manage telecentres that lead to social and economic development? (3) What factors impact telecentre usage? (4) What factors affect inclusion/exclusion from community telecentres? In response to these questions researchers [11, 22, 23, 57] have proposed a range of issues for investigation: (a) contextual features, (b) stakeholder partnerships; (c) community participation in telecentre development and (d) literacy and local content. In the following section we discuss some of the research on these issues.

\subsection{Factors influencing telecentre success}

It has been argued that more research is needed regarding what contextual and individual factors influence telecentre success and sustainability because there is still uncertainty in the development community [23]. In reporting findings from a field study, Mphahlele and Maepa [45] argued that telecentre 
success is influenced by the method by which needs assessments for proposed telecentres are conducted, community marketing strategies, the level of support from the community, the level of telecentre management skills and effective training for telecentre managers. It has also been argued that the motivation of telecentre staff and type of service they offer users in the community is essential $[15,36]$.

A recent study by Romm and Taylor [58] which investigated project-related environmental factors, found that autonomy and harmony are two important factors influencing success of community informatics projects. Another factor found to be important to telecentre success is partnerships among stakeholders [41, 57]. Madon et al. [42] also argue that the institutionalization of telecentre projects often requires careful management of networks and partnerships. Telecentres in the developing world are generally dependent on governments and non-governmental organizations (NGOs) for resources which can be vulnerable to competing interests or conflicts between policy makers and NGOs [57]. Consequently, Roode et al. [59] suggest that alignment of interests of different stakeholders is essential to the success of telecentres. Bailur [3] who studied financial, social and political factors of telecentre success argues that stakeholder theory could help with difficulties in identifying and managing stakeholders' interests.

Community participation in the development of telecentres is identified as essential to success and sustainability [7, 57]. Participatory design of community telecentre services is seen as a useful strategy for removing barriers that help sustain certain inequalities in communities and negatively influence telecentre success and sustainability [21, 58]. This approach looks beyond access and examines the purpose for which the ICTs are being used to find effective ways for community involvement in determining technology services $[8,12,21]$. However, many telecentre initiatives are developed without involving the communities and therefore may not adequately address issues of exclusion such as literacy, education and social status [17]. In a study of telecentres in rural India, it was found that telecentre users were generally the more educated, younger persons from better socio-economic backgrounds than non-users [37]. Similarly, studies have found that some disadvantaged groups were excluded from telecentres in Uganda and Peru [27, 36]. Bailur [3] argues that literacy is a key factor influencing inequality of access and exclusion in telecentres in developing countries. In this regard, Ngwenyama et al. [46] have also argued that people cannot access and benefit from online information resources without appropriate education.
In some of the literature, literacy is viewed as a key factor affecting inclusion and marginalization in community telecentres and a barrier to achieving social and economic gains from ICTs [54]. Several research projects have investigated this issue. For example, it has been found that literacy levels and education (also age and gender) influenced the use of telecentres [14]. DiMaggio and Hargittai [12] also found that low literacy levels affected autonomy in usage of telecentre services. Further, Middleton and Sorenson [44] found that low literacy affected user privacy and freedom of use because of the need for assistance in negotiating the technology. In an evaluation of community multimedia centres (CMCs) established by UNESCO, it was noted that low literacy levels reduced the number of potential users and affected the revenue generation capacity of CMCs in Jamaica [10]. This is the view expressed in much of the research on literacy and the use of ICTs. However, Osborn [48] notes that issues relating to language, literacy and ICTs have not been thoroughly investigated.

Literacy and language are linked in the literature to another success factor - the availability of local content. Local content is seen as a means of engaging users of community ICTs [49]. It has been noted that English is the dominant language of Internet content and a barrier that increases the digital divide [29]. This view is corroborated where language is seen as a primary challenge to providing access to communities that do not use English [22, 60].

While prior research has examined several factors that influence telecentre success, there has been limited research on some of the social issues impacting the usage, success and sustainability of telecentres $[18,24$, $39,47]$. In this paper we seek to extend understanding of factors that influence telecentre usage and success in developing contexts. The next section presents the context and methodology of this research.

\section{Research Context and Methodology}

\subsection{The Jamaican Context}

Jamaica is an island nation in the Caribbean Sea with a population of 2.7 million people. Each of its fourteen parishes can be geographically defined by a parish capital, main towns and rural areas. The capital city of Jamaica is Kingston; this city together with surrounding areas is known as the Kingston Metropolitan Area (KMA), and is home to approximately 1.6 million $(59 \%$ of Jamaica's population). The 2001 Jamaica national census found that the percentage of households with a computer ranged from $6.4 \%$ to $21.4 \%$ of homes across the 
parishes and that $1.2 \%$ to $13.2 \%$ of homes had access to the Internet. While these numbers do not account for the total number of users of the Internet; the International Telecommunications Union reports that in 2001 there were 100,000 Internet users in Jamaica corresponding to $3.8 \%$ of the population. The most recent Jamaica Survey of Living Conditions [50], which includes data collected on the percentage of households with a computer and access to the Internet, provided the following breakdown by area presented in Table 1 below. The Jamaican government has embarked on initiatives in an effort to increase the availability and use of information and communication technologies (ICT) in Jamaica. In a global assessment of the percentage of GDP expended on ICTs in 2003, Jamaica ranked second and was one of the six developing nations that ranked among the top ten in expenditures in this area [68]. However, the ministry with responsibility for telecommunications and ICTs recently indicated that there continues to be limited access to computers for many citizens and efforts persist in addressing these issues through the establishment of access points in communities [33].

In 2006 the Government of Jamaica announced a plan to improve ICT access to its citizens with the objective of improving their quality of life. The Jamaican government's national ICT strategy for 2007-2012 outlined a roadmap for 'e-Inclusion: Open Access to ICTs'. The strategic objectives of this programme are improvements in education, training, job creation, e-government, innovation and creativity [13]. Major policy goals include increased availability of computers with Internet access and a higher level of diffusion of ICTs in rural and inner-city communities.

\section{Table 1. Computer and Internet Access}

\begin{tabular}{|l|c|c|}
\hline \multicolumn{1}{|c|}{ Area } & \multicolumn{2}{|c|}{2006} \\
\cline { 2 - 3 } & $\begin{array}{c}\text { Percentage of } \\
\text { Households } \\
\text { with a } \\
\text { computer }\end{array}$ & $\begin{array}{c}\text { Percentage of } \\
\text { Households } \\
\text { with Internet } \\
\text { access }\end{array}$ \\
\hline $\begin{array}{l}\text { Kingston } \\
\begin{array}{l}\text { Metropolitan } \\
\text { (KMA) }\end{array}\end{array} \quad 12.9$ & 5.3 \\
\hline Other Towns & 12.8 & 6.9 \\
\hline Rural & 11.9 & 3.4 \\
\hline
\end{tabular}

Source: [50]

A primary vehicle for delivery has been community telecentres. Some telecentres were specifically established to target 'unattached' youth who are not in school or are unemployed. Others focus on providing school children with additional resources (access and training) such as computer labs when specific schools are not able to fully meet the usage demands outside of scheduled classes. Still others focused on providing computer training and ICT skills to enhance the potential for employment of a large percentage of the Jamaican labour force $(77.3 \%)$ that have no professional, technical or vocational training [51]. This objective is facilitated by a programme established to help communities improve education, health care, agriculture, and enterprise opportunities.

\subsection{Telecentre Projects in Jamaica}

There have been a number of public and private sector partnerships which have established communitybased telecentres in Jamaica. One of the earliest telecentre initiatives, the Jamaica Sustainable Development Network (JSDN), was established with the support of the UNDP. JSDN's vision is stated as 'Citizens actively making use of understandable, relevant information to enhance the quality of life within their communities for present and future generations.' The mission of the JSDN is 'To enhance citizens' capacity to access, understand, distribute and utilize information to enable them to sustain their livelihoods and socio-cultural values while conserving their natural environment' [34]. The JSDN programme was started in 1998, and an NGO was formed in 2002. The JSDN has established telecentres focusing on the delivery of computer training and access to the Internet to support its mission.

Another initiative, which involves the development of community multimedia centres, which include a radio station as part of the facility, was sponsored by UNESCO. The government has enhanced its efforts to establish more community access points across Jamaica, through collaboration with the Inter-American Development Bank (IDB). Eleven community access points have been established in marginalized communities under this project and thirty more are planned [32]. Prior to this, there have been initiatives to establish Internet access points in all libraries and post offices. The Jamaica Library Service has been successful with this project. There have also been some private sector partnerships with communities in an effort to establish telecentres in neighbouring communities to their businesses or in the communities in which they operate.

\subsection{Research Method}

This study examines four telecentres in Jamaica using a qualitative research methodology. The telecentres were purposively selected in order to have a heterogeneous sample providing different contexts in which to investigate the various phenomena. The telecentres are located in four different parishes in the island. Two of the telecentres are located in small towns in rural areas and two are located in urban areas, 
one of these being in the capital city of Kingston. The telecentres are hosted by community-based organizations (CBOs) and non-governmental organizations (NGOs), and these telecentres are an integral part of community development activities organized by the CBOs and NGOs, providing public access to ICTs.

Data collection entailed in-depth semi-structured interviews and direct observation at the telecentres. This provided multiple sources of data. Direct observation also enabled the researchers to interact with telecentre users in their social context, providing greater detail in the research findings and facilitating several empirical observations. Two rounds of interviews were conducted with managers of the telecentres. Interviews were conducted on site at the telecentres and via telephone. There was also observation of persons using telecentre facilities and services and observation of training sessions in progress. Relevant documents, including information on services offered, activities and a historical overview, were also collected from the telecentres and from their websites. Interview notes and field notes, along with the documents collected, were then analysed to identify themes and concepts.

Following Roman and Colle [57] who argue that a systemic approach should be considered for the formulation of a grounded theory of telecentres, we use a grounded theory approach in our data analysis. We followed the procedures described by Glaser [19], as they enabled us to systematically generate key concepts and relationships from our empirical data. In the grounded theory approach a concept is defined as 'an emergent social pattern grounded in research data'. The conceptual framework presented in this paper was developed using the grounded theory approach of Glaser [19].

\section{Context and Use of Telecentres}

The telecentres which participated in this study are hosted by non-governmental organizations or community-based organizations. One of the telecentres is hosted by the Caribbean Coastal Area Management Programme (CCAM), an environmental NGO in the parish of Clarendon which aims to conserve the natural resources of the protected coastal area it is in close proximity to. The second is the Bluefields People's Community Association (BPCA) Resource Centre in the parish of Westmoreland, which also houses several community facilities, a basic school, fishermen's society, a canteen, and a tour company. The third telecentre is hosted by the International School of Jamaica (ISJA) in St. Mary and is located in a small commercial plaza. Finally, one of the urban telecentres, is hosted by the JSDN office in Kingston, is located as part of a post office complex.

The telecentres provide ten to twenty computers and access to the Internet and computer and life skills training. Telecentre services are utilized in various ways by persons in the surrounding communities. Telecentre managers report that there are a variety of activities facilitated, Internet research by students and teachers, communication, online messaging, online dating, online applications, graphics / documents production.

Under an umbrella programme of the JSDN - the UNDP / Microsoft Project for Disadvantaged Youth, telecentres train youth in ICT basics as well as personal and professional development skills. Potential participants are selected based on criteria established by the telecentre, civic associations and sponsoring organizations. At the telecentres, several staff members have observed during the application process or while training participants in introduction to computers and Internet, that some were not literate. They started a literacy training programme, but it has stopped due to the lack of available resources, including the limited licenses available for a commercial software package. In addition, due to the use of the Creole language, a local software developer has written software with familiar local words which the telecentres are planning to incorporate when a new training programme starts. However, telecentre staff report that they still face the challenge of actually conducting the classes as participants do not want others to know that they are not literate. The literacy programme therefore has to be kept separate from the IT training, and it is a challenge to keep it a secret. At one telecentre, it was noted that while some persons are willing to dedicate time to becoming literate as a stepping stone to utilizing the computers, others focus on learning how to accomplish certain tasks using the computer without going through the stage of becoming literate. Sometimes this is not done in the formal, public setting of telecentre classes, but through friends and one-toone interaction at the telecentre.

Telecentre staff noted however, that despite the challenges presented to users with low literacy levels, the users are motivated by the need to use the telecentre and ask for assistance from staff, other users, friends and family in order to complete what they would like to be done. In some cases, older telecentre users seek assistance from younger family members or other users. Examples were cited of illiterate persons who encouraged others who were literate to use the telecentre, in the process extending the number of persons they could call on for assistance.

The managers and staff at the telecentres are also aware of the expectations of participants that 
completion of the training programme will enhance employment prospects. As a result of the training received at the telecentres, participants who are not currently employed feel empowered to seek employment. Finding employment for the youth who have been trained is a challenge, however there has been some success in placing some of the trainees or assisting with entrepreneurial activities.

The telecentres also maintain contact with participants, and some are hired to work on other shortterm projects such as interviewing and data entry for surveys in the communities. Telecentre managers are currently working on proposals on areas such as sustainable community tourism and alternative livelihoods which they hope will result in job creation.

\subsection{Summary of Key Empirical Findings}

An analysis of the data collected suggests that social ties, location of the telecentres, literacy of the users and perceived opportunities for employment for those able to use computers played a significant role in telecentre success in Jamaica (see Appendix A for empirical evidence). The role of social ties was one of the key findings that emerged from the data collected through interviews and observation. There was evidence of the influence of both strong and weak ties, as well as social ties that were pre-existing and those that were enhanced through use of the telecentres. Strong ties were seen in interactions between family members. For example, one telecentre manager noted that 'They encourage their children to use the Internet, and they keep in touch with their families who live overseas'. This was in reference to older persons who saw the benefit of using the telecentres to maintain links with family members. They may not use the computers regularly themselves, but supported its use among the younger generation. Another telecentre manager reported that 'sometimes their children abroad say to them, 'Mummy, Daddy, I can send you an email you know, it's cheaper'. In this way, strong social ties prompted the older family members to use the services at the telecentre in order to increase communication while conserving on communication costs.

The formation of weak social ties and the strengthening of social ties through organizational interaction were also some of the empirical observations in this study. Telecentre staff reported that 'Participants in the training sessions make friends in class and communicate with them after'. These ties encouraged users to return to use the telecentres, sometimes to meet friends at the telecentre or to communicate with them online. Social ties were also established through interaction among members of the
NGOs and CBOs as telecentre managers highlighted plans to develop networks and communication mechanisms as seen in these comments - 'Our goal is to network participating groups electronically' and 'There has been some amount of email interaction among the NGO community'.

The influence of the location of the telecentres formed a key empirical observation of the study. The host organization and environment in which the telecentres were located influenced the level of activity among telecentre users. Initially, community telecentres were seen primarily as an access point for those who did not have access to computers and the Internet at home. However, telecentre staff noted that persons within the community who have access to computers at home also visit the telecentres. The proximity of the telecentre to other businesses, schools and community activities played a role in the level of usage and the social interactions at the telecentre. This is evidenced by the following comments from interviews - 'The only other cybercentre that I know of anywhere near is in the next town' and 'We have the cybercentre, a basic school, fishermen's society, tour company, all here as part of the community resource centre'.

Literacy played a key role in the use of telecentres presenting both challenges and a means of motivation to telecentre users. Telecentre staff noted that ' $W e$ found while training participants in Intro to Computers and the Internet that some were not literate'. Based on this discovery, staff realized that despite the challenge of illiteracy, persons were still motivated to use the telecentre, particularly if they had a network of social ties. As a result of this development, telecentre staff organized literacy programmes but highlighted that 'The literacy programme has to be kept separate from the IT basics class, and it is still a challenge to keep it secret'. In some cases, gender issues were also involved as one of the telecentre managers noted that 'The ones who gladly take up the beginners' literacy class are the females; the men pretend they can read, but they still want to learn how to burn CDs'. 'What the men want to do is learn the things that can help them financially even if they can't read - like how to connect up a laptop to use with a sound system'

Based on the analysis of the data, perceived opportunities for employment influence the usage of telecentres. Despite the challenges faced by telecentre staff in finding employment for users, persons were still motivated to participate in training sessions and volunteer at the telecentres, as seen in comments from the interviews:. 'There are volunteers who help out with the programme, and sometimes they get job placements after'. 
These key empirical findings provide the platform for the development of a conceptual framework that could inform future research on telecentre success.

\section{Theorizing about the findings}

In order to provide a theoretical explanation of the four key empirical findings (social ties, literacy, location, and economic opportunity), we turned to the literature. A systematic examination of the literature yielded some insights which will now be discussed. While attempts by other researchers to understand the factors affecting telecentre success have led to theorizing about diffusion and adoption of telecentres, and telecentre characteristics and community characteristics, there has been limited discussion of social ties in these theoretical explanations. However, a search of the literature revealed that factors such as social networks and social capital have an influence on the use of community ICTs and telecentres. Social network theory and social capital theory are two theories that can potentially explain some of the empirical observations. Figure 1 provides a graphical description of the key concepts and relationships derived from the empirical evidence that we will now consider in more detail in a theoretical discussion.

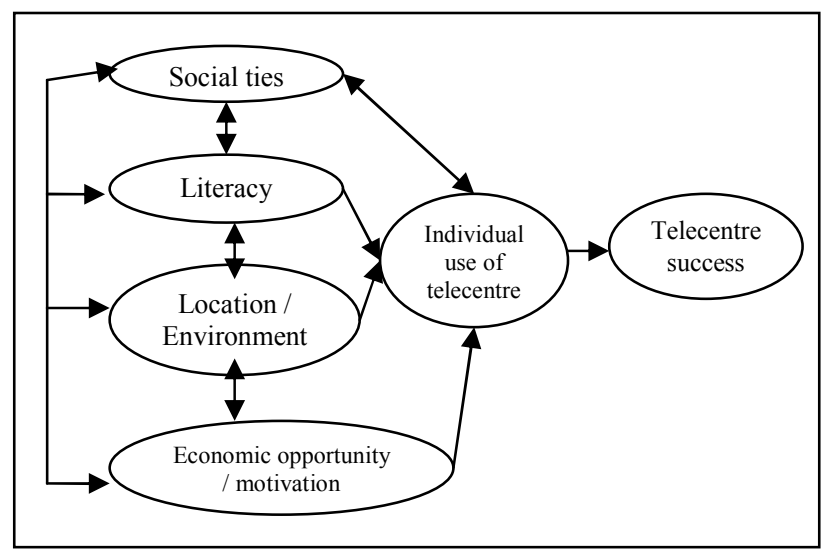

Figure 1. Conceptual Framework

\subsection{Social Ties}

Social network theory (SNT) focuses on understanding social relationships (weak and strong ties) and their implications for individuals and groups. Granovetter [20] highlights the significance of social networks for communication and social support in community organizations. Social capital theory is related to SNT in that it provides a framework for understanding what results from social relationships (social capital) [43]. Putnam [53] defines social capital as 'features of social organization such as networks, norms, and social trust that facilitate coordination and cooperation for mutual benefit.' Bonding social capital occurs when a community is accessing resources within itself, building on strong ties. Bridging social capital occurs when a community is accessing resources outside itself, building on weak ties.

In an assessment of studies focusing on ICTs and social networks and social capital in communities, Williams [67] argues that there is limited understanding of the role of strong and weak ties in the process of establishing and sustaining community ICTs. While some researchers have suggested that SNT and social capital are important perspectives from which to investigate community ICTs, there is yet no theory that includes these concepts and limited empirical work in this area $[38,62]$. We have found that existing social networks may influence participation in telecentre activities. Further, social networks developed as a result of telecentre interaction may also influence usage and telecentre success. As DiMaggio and Hargittai, [12] suggest, social support, through both formal and informal interaction, is a positive influence on community ICT use. The more social ties telecentre users have, the more they will use the telecentre [65]. Consistent with these arguments, Bonadia et al. [5] propose that social ties are a key factor in modeling telecentre acceptance and use.

It is equally important to note that our empirical observations suggest that the use of telecentres support the development and deepening of social ties. Other researchers have found that some ICT communicative initiatives have had the specific goal of developing social ties [16]. These social ties and the density of social networks in the community increased as a result of online and offline interaction. Pinkett [49] also found that social networks were expanded through participation in a similar project and this finding was further supported by Haythornthwaite [25] who noted the role of ICT usage in creating and enhancing social ties. Based on our empirical findings and support from the literature on social networks and social ties we state two propositions:

Proposition 1: When the number of social ties is high, it is likely that telecentre use will be high.

Proposition 2: When telecentre use is high, it is likely that the number of social ties will be high.

It is also important to note that social networks emerging from telecentre use can lead to social capital which can influence social and economic development. As Warschauer [64] argues, access to computers can translate into access to the information society which is important for computer and Internet use to enhance social capital. Kanungo [35] argues that the value of rural information systems should be assessed in terms of the social capital created in addition to the economic 
value. Adler and Kwon [1] present the concept of social capital as it relates to individuals or groups, noting that opportunity, ability and motivation are sources of social capital. This theory underpins several of the constructs in the framework, as social capital is utilized or created in the interactions among telecentre staff, telecentre users and the community in relation to their membership in social networks, employment prospects, and literacy.

\subsection{Literacy}

Low literacy levels are considered a barrier to achieving the objectives of telecentres in developing countries. For example, it was found that low literacy levels negatively influenced telecentre use in Africa [14]. Lee [40] states that making Internet access available, even if it is free, to people who are not literate, is useless. However, Hudson [28] found that in emergencies necessitating the use of ICTs, literacy does not negatively influence use. High levels of literacy and education are viewed as key factors positively influencing telecentre use [36]. But low levels of literacy and educational resources in the community have been found to increase the demand for telecentre services [41]. Empirical evidence from this study demonstrates that persons who do not have the basic literacy necessary for participation in telecentre training were very much interested in attending the training sessions and sometimes tried to hide their level of literacy. In some cases the trainers were not aware of these issues until the first task requiring reading or writing skills.

In developing contexts, literacy is often correlated with gender. For example, Roman and Colle [57] suggest that women may be excluded from using telecentres due to literacy levels and gender. However, empirical evidence from our study indicated that women who were not literate were more likely than men to participate in literacy classes in order to join telecentre programmes. We also found that telecentre users with low literacy used existing relationships and developed new ones (younger family members, trusted community members, or other telecentre users) for assistance with the technology. These social ties were also utilized in attaining higher levels of literacy in order to use the telecentre services on their own. We propose that there is a relationship between social ties and literacy in the use of telecentres. Social ties may enable community members with low literacy to use telecentres. While increasing literacy will be related to increasing telecentre usage, increasing social ties will enable those with low literacy to increase their use of the telecentres.
Proposition 3: When literacy levels are high, it is likely that telecentre use will be high

Proposition 4: When literacy levels are low, and the number of social ties is high, it is likely that telecentre use will be high

\subsection{Location and Environment}

An empirical observation of this study is that location is a key factor in telecentre success. Other research has also found that location has an effect on the use of telecentres $[9,14,37]$. Development organizations have argued that telecentres are more successful when clustered with other existing centres for community activities [31]. Schools, post offices and libraries are also suggested as good locations [52]. However, Roman and Colle [57] argue that libraries may not be suited for community telecentres as such locations may be intimidating for some potential users. Some researchers believe that telecentre users with limited educational may prefer informal communitybased environments [26]. A familiar location which is used by the community for various purposes may be less daunting to users. The atmosphere and organizational environment when linked with social aspects seem to influence the use of technology. Bonadia et al. [5] have also suggested considering both proximity to the telecentre and whether a user feels connected to the telecentre through social networks. We would argue that the location of the telecentre, and the environment will help to determine the extent of the utilization of the telecentre services and facilities. This leads to the fifth proposition, stated below.

Proposition 5: When telecentre location and environment are conducive, it is likely that telecentre use will be high.

\subsection{Economic opportunity / motivation}

Rogers and Shukla [55] described the telecentre as an innovation which had a rapid rate of diffusion and was poised to do well based on its position in the 'takeoff' region on the adoption curve between early and late adopters. This provides a perspective for examining perceived economic opportunities and telecentre use. Users who see the potential for employment may be early adopters of the services offered by telecentres [28]. Through communication channels in the community, other persons may be motivated to use the telecentre directly or through social ties to pursue potential economic opportunities.

Mutual benefits can be derived from the training and promotion of employment opportunities for telecentre users. Telecentres can also benefit from the cadre of trained users. Clark [7] also posits that 
persons who volunteer to work at a telecentre may be interested in employment opportunities and participating in further training.

Proposition 6: When economic opportunities and motivation are high, it is likely that telecentre use will be high.

\section{Implications for Future Research}

In this paper we have presented a theoretical framework for studying telecentre success in developing countries based on empirical evidence from field research and theoretical argumentation. Presently while there are discussions about this phenomenon there are no accepted theories in the literature. Research in community informatics combines ICT theories with the practice of community development [47] and it is argued that community informatics theory and approaches are currently emerging [21, 24], although in a limited way $[47,62]$. With specific focus on telecentres, Harris [24] argues that there is a critical need for a general theory on the factors influencing telecentre success. This view is congruent with Roman [56] who notes the absence of theory-based research in studies on telecentres. Some researchers have highlighted the lack of conclusive research, the reliance on anecdotal evidence, and the fragmented nature of the research, and argue that a body of theory needs to be developed in the area of community informatics and ICTs for development [49, 58, 61]. For example, Roman [56] argues that due to the many inter-related levels of analysis involved in telecentre research, a single theoretical lens may not be adequate in framing the research. The relationship between people, social institutions and technology is complex and dynamic [18]. This highlights the importance of the role of social, economic and cultural contexts in investigating the effects of ICTs on communities as outlined by Avgerou [2].

Our framework which combines the concepts of social ties, location and environment, literacy and perceived economic opportunity and their relationships with telecentre usage and success offers a fertile theoretical framework through which further research can explore the phenomena. Our study makes a unique contribution to research by developing a framework for future research by combining empirically grounded findings, together with theoretical explanations from the social science literature. Further, our study contributes to practice by identifying factors that can influence telecentre usage and success in developing country settings. With the current interest in the impact of ICTs for development and best practices, it is useful for researchers, policy makers and practitioners to have a model of telecentre use, since usage is a key contributor to success and sustainability. The proposed framework can be used to help guide the process of introducing new telecentres by assessing the potential usage of the facilities based on their local context or promoting the use of existing telecentres for community development. Given that the objective of telecentres is to provide public access to computers and the Internet with the aim of enhancing individual and community development it is important that policy makers and telecentre managers understand the factors that influence usage and success.

While our study makes a contribution both to the theory and practice of community informatics it has some limitations. We investigated four telecentres supported by a range of partners including NGOs, community-based organizations, government and multilateral agencies in a specific developing country setting. Our research was conducted using qualitative research methodology and a grounded theory approach to analyze the data. As such our findings, the concepts that are generated from which a framework is developed, will need to be investigated in more settings before more general claims can be made about this proposed theoretical framework. However, Walsham et al., [63] have pointed out that more research involving the role of these organizations in information systems in developing countries is needed. Future research could help enhance our understanding about the relationships between social ties, literacy, centre location and economic motivation on telecentre usage and success at the community level. Further, research on the characteristics and usage patterns of telecentre users could be a step towards answering the call from the International Telecommunication Union [30] and the World Bank [68] for the use of indicators which take into account community access initiatives instead of depending solely on the traditional measures of universal access which may not accurately reflect the extent of the use of ICTs for development. Another issue that needs investigation is local content, which has been raised as a factor which impacts telecentre success, combined with the key element of literacy identified in this study. This issue also highlights the need for more systematic investigation of local contexts in which telecentres are situated to determine how local content and content delivery methods, taking into account the available skills and resources, might affect participation of community members.

\section{References}

[1] Adler, P. and Kwon, S., Social Capital: Prospects for a New Concept, Academy of Management Review, 27, 1, 2002, pp. 17- 40 . 
[2] Avgerou, C., The Significance of Context in Information Systems and Organisational Change, Information Systems Journal, 11, 2001, pp. 43-63.

[3] Bailur, S., Using Stakeholder Theory to Analyze Telecenter Projects, Information Technologies and International Development, 3, 3, 2006, pp. $61-80$.

[4] Barnola, L. and Pimienta, D., Mistica: A Collective Endeavor - In Search of the Social Impact of ICTs in Latin America and the Caribbean, TechKnowLogia, 3, 4, 2001, pp. $40-44$.

[5] Bonadia, G., Avila, I., Ogushi, C. and de Holanda, G., Modeling the Acceptance and Use of Telecenters in Brazil, Journal of Technology Management and Innovation, 2, 4, 2007, pp. 86-97.

[6] Castells, M., Grassrooting the space of flows, in Wheeler, J., Aoyama, Y., and Barney, W. (eds.), Cities in the telecommunications age: the fracturing of geographies, Routledge, London, 2000, pp. 18-27.

[7] Clark, J., Promoting Participation in Telecentres, Journal of Development Communication: Special Issue on Telecentres, 12, 2, 2001.

[8] Clement, A. and Shade, L., The access rainbow: conceptualizing universal access to the information/communications infrastructure. Community Informatics: Enabling Communities with Information and Communications Technologies, Gurstein, M. Hershey, PA, Idea Group Publishing, 2000, pp. 32-51.

[9] Colle, R., Memo to Telecenter Planners, Electronic Journal of Information Systems in Developing Countries, 21, 1, 2005, pp. 1-13.

[10] Creech, H., Evaluation of UNESCO's Community Multimedia Centres, 2005, UNESCO.

[11] Day, P., Sustainable Community Technology: The symbiosis between community technology and community research, The Journal of Community Informatics, 1, 2, 2005, pp. 4-13.

[12] DiMaggio, P. and Hargittai, E., From the 'Digital Divide' to 'Digital Inequality': Studying Internet Use as Penetration Increases, Woodrow Wilson School, Princeton University, 2001.

[13] Dunn, H. and Duggan, E., E-Powering Jamaica National ICT Strategic Plan, 2007-2012, Prepared for the Ministry of Industry, Technology, Energy and Commerce, Government of Jamaica, 2006.

[14] Etta, F. and Parvyn-Wamahiu, S., Information and Communication Technologies for Development in Africa. Vol. 2: The Experience with Community Telecenters, International Development Research Center (IDRC), Ottawa, 2003.

[15] Fuchs, R., Little Engines That Did - Case Histories from the Global Telecentre Movement, IDRC, 1998.

[16] Gaved, M. and Anderson, B., The impact of local ICT initiatives on social capital and quality of life, Chimera Working Paper 2006-06, University of Essex, 2006.

[17] Gaved, M. and Mulholland, P., Grassroots Initiated Networked Communities: A Study of Hybrid Physical/Virtual Communities, Proceedings of the $38^{\text {th }}$ Hawaii International Conference on System Sciences, Hawaii, 2005.

[18] Gigler, B., Including the Excluded- Can ICTs empower poor communities? Towards an alternative evaluation framework based on the capability approach, $4^{\text {th }}$ International Conference on the Capability Approach, 5-7 September, University of Pavia, Italy, 2004.

[19] Glaser, B., Conceptualization: On theory and theorizing using grounded theory, International Journal of Qualitative Methods, 1,2, 2002.

[20] Granovetter, M., The Strength of Weak Ties, American Journal of Sociology, 78, 1973, pp. 1360-80.

[21] Gurstein, M., Effective use: A community informatics strategy beyond the digital divide, First Monday, 8, 12, 2003.

[22] Gurstein, M., Rural Development and Food Security, A Community Informatics Based Conceptual Framework, Proceedings of the $34^{\text {th }}$ Hawaii International Conference on System Sciences, 2001, Hawaii.

[23] Harris, R., Kumar, A. and Balaji, V., Sustainable Telecentres? Two Cases from India, in The Digital Challenge: Information Technology in the Development Context, Krishna, S. and Madon, S. (eds.), Chapter 8, 2003, pp. $124-135$.

[24] Harris, R., Telecentres in Rural Asia: Towards a Success Model, Proceedings of the International Conference on Information Technology, Communications and Development, November, Kathmandu, Nepal, 2001.

[25] Haythornthwaite, C., Social networks and internet connectivity effects, Information, Communication and Society, 8, 2, 2005, pp. $125-147$.

[26] Hellawell, S., Beyond Access: ICT and Social Inclusion, Glasgow: Fabian Society, 2001

[27] Holmes, V., The Internet, inequality and exclusion in Peru: the social impact of the cabinas publicas, Unpublished master's thesis, Institute of Latin American Studies, University of London, 2001.

[28] Hudson, H., Telecenter Evaluation: Issues and Strategies, in C. Latchem and D. Walker (eds.) Telecenters: Case Studies and Key Issues, The Commonwealth of Learning, Vancouver, 2001.

[29] Huerta, E. and Sandoval-Almazán, R., Digital literacy: Problems faced by telecenter users in Mexico, Information Technology for Development, 13, 3, 2007.

[30] International Telecommunication Union, Recommendation 1, Adoption of Information and Communication Technology (ICT) Community Access Indicators and Indices, Workshop on ICT community access indicators, Mexico City, 2003.

[31] International Telecommunication Union/United Nations Conference on Trade and Development, World Information Society Report 2007: Beyond WSIS, 2007.

[32] Jamaica Information Service, Telecoms Ministry to Establish More Community Access Points, 2007.

[33] Jamaica Observer, More Jamaicans to access computers - Mullings, February 14, 2008.

[34] Jamaica Sustainable Development Network (http://www.jsdnp.org.jm) - accessed 20/11/ 2007.

[35] Kanungo, S., On the emancipatory role of rural information systems, Information Technology and People, 17, 4, 2004, pp. $407-422$.

[36] Kintu, F., Obot, D. and Elder, The Uganda Knowledge and Information Society: Early Lessons from ICT 
Projects, in At the Crossroads: ICT Policy making in East Africa, Etta, F. and Elder, L. (eds.), 2005.

[37] Kumar, R. and Best, M., Social Impact and Diffusion of Telecenter Use: A Study from the Sustainable Access in Rural India Project, Journal of Community Informatics, 2, 3, 2006.

[38] Kvasny, L. and Keil, M., The Challenges of Redressing the Digital Divide: A Tale of Two Cities, Twenty-Third International Conference on Information Systems, 2002, pp. 817-828.

[39] Kvasny, L. and Lee, R., Towards a Framework to Enhance the Technology Capacity of Community-Based Organizations in Urban Contexts, Ninth Americas Conference on Information Systems, 2003.

[40] Lee, J-W., Education for Technology Readiness: Prospects for Developing Countries, Journal of Human Development, 2, 1, 2001, pp. $115-151$.

[41] Madon, S., Governance lessons from the experience of telecentres in Kerala, European Journal of Information Systems, 14, 2005, pp. 401-416.

[42] Madon, S., Reinhard, N., Roode, D. and Walsham, G., Digital Inclusion Projects in Developing Countries: Processes of Institutionalisation, Proceedings of the $9^{\text {th }}$ International Conference on Social Implications of Computers in Developing Countries, Brazil, 2007.

[43] Meredyth, D., Hopkins, L., Ewing, S. and Thomas, J., Measuring Social Capital in a Networked Housing Estate, First Monday 7, 10, 2002.

[44] Middleton, C. and Sorensen, C., How Connected are Canadians? Inequities in Canadian Households' Internet Access, Canadian Journal of Communication, 30, 4, 2005.

[45] Mphahlele, M. and Maepa, M., Critical success factors in telecentre sustainability: a case study of six telecentres in the Limpopo Province, Communicatio, 29, $1 \& 2,2003$, pp. $218-232$.

[46] Ngwenyama, O., Andoh-Baidoo, F., Bollou, F., Morawczynski, O., Is There a Relationship between ICT, Health, Education and Development? An Empirical Analysis of Five West African Countries from 1997 - 2003, Electronic Journal of Information Systems in Developing Countries, 23, 5, 2006, pp. 1-11.

[47] O'Neil, D., Assessing community informatics: a review of methodological approaches for evaluating community networks and community technology centers, Internet Research: Electronic Networking Applications and Policy, 12, 1, 2002, pp. $76-102$.

[48] Osborn, D., African Languages and Information and Communication Technologies: Literacy, Access, and the Future, Selected Proceedings of the 35th Annual Conference on African Linguistics, ed. John Mugane et al., Massachusetts, 2006, pp. 86-93.

[49] Pinkett, R. (2003) Community Technology and Community Building: Early Results from the Creating Community Connections Project, The Information Society, 19, pp. 365-379.

[50] Planning Institute of Jamaica and Statistical Institute of Jamaica, The Jamaica Survey of Living Conditions 2006, Data provided by the Derek Gordon Databank, University of the West Indies, 2006.
[51] Planning Institute of Jamaica, The Transition of Jamaican Youth to the World of Work, PIOJ, 2006.

[52] Proenza, F., Telecenter Sustainability: Myths and Opportunities, "Bridging the rural knowledge gap: Information systems for improved livelihoods" Dixon \& Wattenbach (Eds.), Rome, 2001.

[53] Putnam, R., Bowling alone: America's declining social capital, Journal of Democracy, 6, 1, 1995, pp. 65-78.

[54] Reilly, K. and Gomez, R., Comparing Approaches: Telecentre Evaluation Experiences in Asia and Latin America, Electronic Journal of Information Systems in Developing Countries, 4, 3, 2001, pp. 1 - 17.

[55] Rogers, E., and Shukla, P., The role of Telecenters in development communication and the digital divide, Journal of Development Communication, 2, 12, 2001, pp. 26-31.

[56] Roman, R., Diffusion of Innovations as a Theoretical Framework for Telecenters, Information Technologies and International Development, 1, 2, 2003, pp. 53-66.

[57] Roman, R. and Colle, R., Themes and Issues in Telecentre Sustainability, Working Papers, University of Manchester Development Informatics, 10, 2002.

[58] Romm, C. and Taylor, W., The Role of Local Government in Community Informatics Success Prospects: The Autonomy/Harmony Model, Proceedings of the $34^{\text {th }}$ Annual Hawaii International Conference on System Sciences, Hawaii, 2001.

[59] Roode, D., Speight, H., Pollock, M. and Webber, R., It's not the digital divide - it's the socio-techno divide!, Proceedings of the $12^{\text {th }}$ European Conference on Information Systems, Turku, Finland, 2004.

[60] Songan, P., Khairuddin A. H., Yeo, A., Gnaniah, J. \& Zen, H., Community Informatics: Challenges in Bridging the Digital Divide, Proceedings of the Seventh Conference on Work With Computing, 2004.

[61] Stoecker, R., Is Community Informatics good for communities? Questions confronting an emerging field. The Journal of Community Informatics, 1, 3, 2005, pp. $13-26$.

[62] Taylor, W. and Marshall, S., Collaboration: the Key to Establishing Community Networks in Regional Australia, Informing Science, 5, 3, 2002.

[63] Walsham, G., Robey, D. and Sahay, S., Foreword: Special Issue on IS in Developing Countries, MIS Quarterly, 31, 2, 2007, pp. $317-326$.

[64] Warschauer, M., Social capital and access, Universal Access in the Information Society, 2, 4, 2003, pp. 315330.

[65] Wellman, B., Salaff, J., Dimitrova, D., Garton, L., Gulia, M., and Haythornthwaite, C., Computer Networks as Social Networks: Collaborative Work, Telework and Virtual Community, Annual Review of Sociology, 22, 1996, pp. $213-238$.

[66] Whyte, A., Assessing Community Telecentres: Guidelines for Researchers, International Development Research Centre (IDRC), Canada, 2000.

[67] Williams, K., Relationship between social networks and ICT use in historical communities, Conference on Computer Supported and Co-operative Work, 2004.

[68] World Bank, World Development Indicators 2005, World Bank, Washington D.C, 2005. 


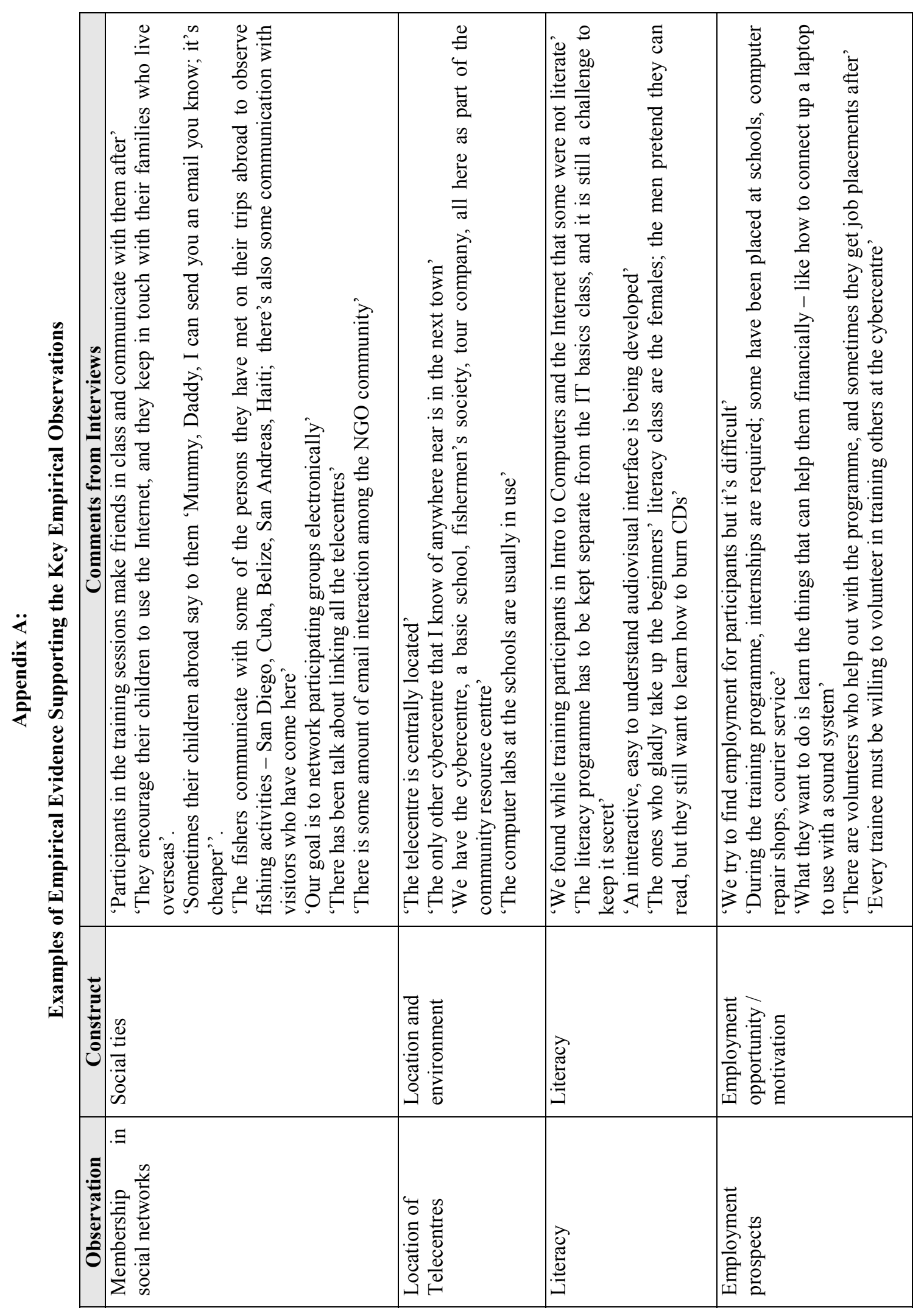

